\title{
Bladder Soft Tissue Neoplasm
}

National Cancer Institute

\section{Source}

National Cancer Institute. Bladder Soft Tissue Neoplasm. NCI Thesaurus. Code C158636.

A mesenchymal neoplasm that arises from the bladder. 